\title{
Interpretation dimensions and research course of employability
}

\author{
Guanghui Chen \\ Qinhuangdao Institute of Technology, \\ Qinhuangdao, China \\ E-mail address: chenguanghui@pku.edu.cn
}

\begin{abstract}
In this paper, we made literature research on the interpretation dimensions and research course of employability. Based on the research, we made literature comment, defined the concept of employability, and inquired into the relationship between employability and talents training under the background of boundaryless career.
\end{abstract}

\section{Keywords-Employability; Interpretation dimensions; Research course; Inspiration}

\section{INTRODUCTION}

The research on the concept of employability first appeared in England, and subsequently it was developed and popularized rapidly in America and Canada. Domestic relative research on employability is proposed in the background of some outstanding problems presented with the mass expansion of higher education, such as the employment difficulty of graduates, the steady increase of "structural contradiction" of students' employment, the abuses of index management of employment rate, etc. In order to have a more deep and more comprehensive understanding and recognition, it is necessary to make literature research and comment on the interpretation dimensions and research course of employability.

\section{INTERPRETATION DIMENSIONS OF EM- PLOYABILITY}

The concept of employability maybe includes seven main explanations in the history research:

\section{A. Describe employability by dichotomy}

This explanation was originated in the beginning of the 20th century, mainly prevailing in England and American and continuing to be used up to 1950s. This interpretation method describes employability by simple dichotomy: one may be suit for employment or not be suit for employment, e.g., if physical health, he may find job rapidly in labor market. This system suffers from criticism frequently, because it neither considers the conditions of labor market nor realizes the difference degree between the conditions of employability and unemployability ${ }^{[1]}$.

\section{B. Employability of social medical}

This explanation is proposed mainly by doctor and rehabilitation doctor, aiming to improve the employability of disabled people and unemployed group in trouble. According to different emphases, measure standard associated with physical disability and social interaction disorder is adopt$\mathrm{ed}^{[2]}$.

\section{Employability of human policy}

This explanation can measure the difference between individual characteristic and labor market, including output demand and reception demand. The second and third explanation was mainly originated in America, obviously having individuation limitation ${ }^{[3]}$. They mainly have an eye to the group that needs help in job hunting, and regard the possible discrimination derived from market conditions and employers as invariable factor.

\section{Flowing employability}

This explanation mainly has an eye to the rate of the job hunting of laid-off workers. This method makes evaluation by the rate of specific unemployed group. By this method, it may no longer classify according to any unemployed group, or classify according to single unemployed person (differential employability).

\section{E. Employability of labor market action}

This explanation considers the related path and statistical information which can be inquired, setting up three special probabilities of defining limitation for group or individual, and using man-hour to denote the probability and pay rate of continuous working period ${ }^{[4]}$. In this sense, it only belongs to neuter, only being used to evaluate one item by tracing type.

\section{F. Initiative employability}

This explanation highlights individual responsibility and ability, and proceeding from personal details, touches the accumulative process of human capital and social capital. It can be defined as the market ability of accumulating personal skills. Its evaluation criteria is the extent of the potentially or already obtained human capital (including knowledge, production capacity, learning ability), as well as the magnitude and quality of the support and help power (social capital) that individual can arouse.

\section{G. Interactive employability}

This explanation introduces interactivity and collectivity again, regarded as "significant relative ability that individual obtains, interacting between individual characteristic and labor market”. 


\section{MAIN COURSE OF EMPLOYABILITY RE- SEARCH}

The research course of employability, from the appearance of its concept to now, generally experienced three phases.

A. First phase (1950s-70s): the early concept of employability

In this period, the research level of employability lies in individual perspective. There are many relative studies in academic circles of England, and it is further developed in America. In America, it is first defined according to the availability rate of ablebodied workers. The viewpoint of this definition attempts to discriminate those who are taken over suitably (unemployable), such as the aged, or those who hunt job (employable). In 1999, Grzier ${ }^{[5]}$ calls the concept of this employability as "employability of dichotomy”. Employability of dichotomy neither considers the conditions of labor market nor discriminate the definition of employability in all circumstances, such as paying no attention to the career flow and transformation of employees, but only investigate how to solve the problem of employment of laid-off workers.

B. Second phase (1980s-the end of 90s): the formation and evolution of the concept of employability

In the early 1980s, the research on employability turned to enterprise or organization level ${ }^{[6]}$. Facing variable external environment, enterprise must obtain adequate flexibility to accommodate the changes. In view of the continuous adjustment and change of production, service and work flow, employability becomes a "meta-characteristic" that employers require their employees to have. The long-term or central employees need to undertake more and more flexibility functions. At the same time, in order to deal with the fluctuation of the demanded quantity of employees and the diversity of neatly adjusting work time to accommodate demand, enterprises also begin to employ temporary workers and part-time workers in large quantities. This arrangement causes that labor market is divided into two parts: a primary part-consist of those who go in long-term jobs; a secondary part-consist of those who sign temporary contract and those who go in for odd jobs.

This means that the improvement of employability therefore becomes a responsibility that governments, employers and individual employees undertake together. Its core is how the three parties balance between responsibility and scope. Whereupon, employability evolves into: a core definition; an extended definition; a whole including definition. The extended definition of employability includes all individual characteristics containing will and ability, deciding the all characteristics of present and future position of individual in labor market. In the 21st century, the research on the concept mode of employability basically follows this thinking. Thus, the concept frame of employability is formed basically.
C. Third phase (from the end of 1990s to now): the concept of employability under the background boundaryless career

The 21st century is an age in which boundaryless career predominates. On the one hand, technological advance and transform accelerates the rate of the destruction and creation of post; at the same time, boundaryless career requests that employees can flow among different posts, professions, functions, roles and organizations. The employability of laborers (including various professional specialities and current skills, such as interpersonal communication skills, learning abilities, organizing and coordination abilities) and the adaptability of dealing with the changes in professional environment appear to be very important for enterprises to obtain sustainable competence advantages.

In this phase, the research on the employability of college students becomes an important and unique area in the research on employability. Because western developed countries and most emerging and developing countries have realized the popularity or massilization of high education, the study perspective of foreign employability transfers to college students and institutions of higher education gradually.

Domestic relative research on employability is proposed in the background of some outstanding problems presented with the mass expansion of higher education, such as the employment difficulty of graduates, the steady increase of “structural contradiction" of students' employment, the abuses of index management of employment rate, etc. Domestic research on employability starts later, the basis is still weak, and making comprehensive and systematical comment on varied study results is rare $^{[6]}$. These studies focus upon the significance, concept, factor, level, etc., and introduce the research of foreign employability.

Chinese government and the relative departments have realized the significance of cultivating employability. 'The National Outline for Medium and Long Term Educational Reform and Development (2010-2020)' issued by the Party Central Committee and the State Council proposes that vocational education should face everyone, face society, strive to cultivate the professional ethics, professional skills, employability and pioneering ability.

\section{ENLIGHTENMENT OF RESEARCH}

\section{A. Research perspective of employability}

Foreign research on employability originates the public policy service for government. Facing the unemployment rate during economic adjustment, government cultivates the employability of laid-off workers to improve the employment rate of the whole society. The research perspective has organization (government) level as well as individual level.

\section{B. Boundary career and employability}


The 21st century is an age in which boundaryless career predominates. The domestic and foreign research on employability rarely places their perspective in the background of boundaryless career to pay attention to the occupation flow and transformation of employees, but emphatically studies how to resolve the problem of employment of individual or the problem of reemployment of laid-off workers. Its leading idea is that individual realizes employment for life inside organization. Doubtless, studying employability form boundaryless career is an inevitable perspective.

\section{REFERENCES}

[1] Fugate, M., et a.l Employability: A Psycho-social Construct and its Dimensions, and Applications, Journal of Vocational behavior, vol. 65, pp. 14-38, 2004.

[2] Hillage J., Pollard E. Employability: development a framework for policy analysis, Research brief 85, Department for education and employment, 1998, pp. 4-8.

[3] Gazier, B. (1999). Employability: concepts and policies. Berlin: European Commission, Employment and Social Affairs.

[4] Feintuch, Alfred. (1955). Improving the employability and attitudes of “difficult to place" persons. Psychological Monographs Series, No. 392. Washington, DC, American Psychological Association.

[5] Bhearmann,R., \& Spill,R.(1988) A Dialogue on employability skills: how can they be taught?Journal of Career Development.Vol.15, pp. 41-47.

[6] Berntson, Erik. (2008). Employbility perceptions,nature,determainations, and implications for health and wellbeing.Printed in Sweeden by US-AB,Stockholm. 